\title{
Salt-dependent succession of phototrophic communities in the soda lake Tanatar VI (Altai Region, Russia)
}

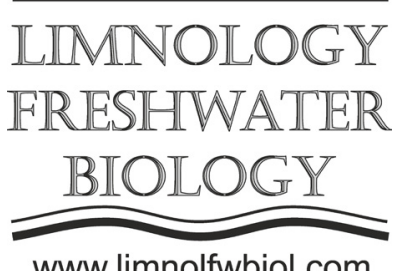

www.limnolfwbiol.com

\author{
Samylina O.S. ${ }^{1 *}$, Namsaraev Z.B. ${ }^{2}$ \\ ${ }^{1}$ Winogradsky Institute of Microbiology, Research Center of Biotechnology, Russian Academy of Sciences, 60 let Oktjabrja pr-t, 7-2, \\ Moscow, 117312, Russia \\ ${ }^{2}$ NRC "Kurchatov Institute", Akademika Kurchatova pl., 1, Moscow, 123182, Russia
}

ABSTRACT. The paper describes the changes that occurred in the ecosystem of soda lake Tanatar VI during the 2011-2019 period when salinity decreased from 160-250 to 13-14 g/l

Keywords: soda lake, Picocystis, cyanobacteria, biological soil crusts, succession, nitrogen fixation

\section{Introduction}

A great number and variety of saline lakes are located in the Kulunda Steppe in the Altai Region. These lakes are exposed to annual and long-standing fluctuations of temperature, salinity, flooding and drying periods due to their locality in the zone of cold arid climate. There are soda lakes among them, which maintain stable alkaline $\mathrm{pH}$ due to a prevalence of soluble carbonates in the brines. Thereby diversity and functioning of phototrophic communities of unique soda lakes are actively studied in recent years (Samylina et al., 2014; 2019; Namsaraev et al., 2018). Ecosystem of Tanatar VI possesses some peculiarities which distinguish it from the previously studied lakes. In the present work, we describe the salt-dependent changes in phototrophic communities in this lake.

\section{Material and methods}

Soda lake Tanatar VI is located near Malinovoe Ozero village in Mikhailovsky district, Altai Region $\left(51^{\circ} 37^{\prime} 08.4^{\prime \prime} \mathrm{N}, 79^{\circ} 48^{\prime} 53.0^{\prime \prime} \mathrm{E}\right)$. Samples of phototrophic biomass were collected from the brine, littoral area, and surface of the moist soil surrounding the lake. Salinity, $\mathrm{pH}$, soluble carbonate alkalinity and potential nitrogen fixation (NF) measurements, as well as identification of algae and cyanobacteria, were performed similarly to previous studies (Samylina et al., 2014; 2019; Namsaraev et al., 2018).

\section{Results and Discussion}

During the observations from 2011 to 2019 the lake passed through periods of high (160-250 $\mathrm{g} / \mathrm{l})$, medium (60-100 $\mathrm{g} / \mathrm{l})$ and low (13-14 $\mathrm{g} / \mathrm{l})$ salinity. Several types of phototrophic communities were detected in the Tanatar VI (Table): 1) Bottom, floating and epiphytic cyanobacterial biofilms (CB); 2) floating and epiphytic Ctenocladus-communities with filamentous chlorophyte Ctenocladus circinnatus and cyanobacteria (CC); 3) Blooms of unicellular algae Picocystis salinarum (P-bloom); 4) Cyanobacterial blooms (CB-bloom); 5) Biological soil crusts (BSC) developed on the moist soil between thickets of Salicornia altaica near the lake. Picocystis-blooms and BSCs were detected each summer since 2012 during periods of high and medium salinity. In contrast to other Kulunda soda lakes cyanobacterial biofilms and Ctenocladus-communities were not massive (except 2011). High-salinity period was characterized by a low diversity of cyanobacteria: unicellular Euhalothece sp. and filamentous Geitlerinema sp., Nodosilinea sp. The diversity increased during the medium-salinity period: heterocystous Nodularia harveyana, filamentous Halomicronema sp., Phormidium cf. etoshii, Spirulina spp. and unicellular Chroococcus turgidus appeared. At the low-salinity period littoral area was flooded; BSCs were replaced by epiphytic cyanobacteria and Picocystis-blooms - by cyanobacterial blooms. Diversity of cyanobacteria increased again, and heterocystous Nostoc cf. paludosum and $N$. cf. punctiforme, unicellular cf. Cyanobacterium cedrorum and Merismopedia warmingiana appeared.

Phototrophic communities with heterocystous cyanobacteria exhibited higher NF potential compared to communities without heterocystous cyanobacteria under the same conditions (Table). Heterocystous cyanobacteria developed in brine at salinity below 60 $\mathrm{g} / 1$ with $N$. harveyana being the most halotolerant. At higher salinity, no vegetative cells of $N$. harveyana were observed in the brine, but they were found in the BSCs.

*Corresponding author.

E-mail address: olga.samylina@gmail.com (O.S. Samylina) 
Table. Succession of phototrophic communities in soda lake Tanatar VI (Kulunda Steppe).

\begin{tabular}{|c|c|c|c|c|c|c|c|c|c|c|c|c|c|c|c|c|c|c|}
\hline \multirow[t]{3}{*}{ Year } & \multirow[t]{3}{*}{$\mathrm{pH}$} & \multirow{3}{*}{$\begin{array}{l}\text { Salini- } \\
\text { ty }(g / 1)\end{array}$} & \multirow{3}{*}{$\begin{array}{c}\text { Total } \\
\text { alkalin- } \\
\text { ity (M) }\end{array}$} & \multirow{3}{*}{$\begin{array}{l}\text { Sam- } \\
\text { pling } \\
\text { site }\end{array}$} & \multirow{3}{*}{$\begin{array}{l}\text { Type of com- } \\
\text { munity (see } \\
\text { text for abbre- } \\
\text { viations) }\end{array}$} & \multicolumn{11}{|c|}{ Dominating cyanobacteria } & \multirow{2}{*}{\multicolumn{2}{|c|}{$\begin{array}{c}\text { Average ARR } \\
\text { (nmol C } \mathrm{H}_{4} / \\
\mathrm{ml} \cdot \mathrm{h})\end{array}$}} \\
\hline & & & & & & \multicolumn{2}{|c|}{$\begin{array}{l}\text { Hetero } \\
\text { cystous }\end{array}$} & \multicolumn{5}{|c|}{ Filamentous } & \multicolumn{4}{|c|}{ Unicellular } & & \\
\hline & & & & & & $\mathrm{Np}$ & $\mathrm{Nh}$ & G & $\mathrm{N}$ & $\mathrm{H}$ & $\mathrm{P}$ & $\mathrm{S}$ & $\mathrm{Ct}$ & $\mathrm{Cc}$ & Mw & $\mathrm{E}$ & Light & Dark \\
\hline \multirow[t]{2}{*}{2011} & 10.0 & 160 & 1.7 & brine & $\mathrm{CC}, \mathrm{CB}$ & & & + & + & & & & & & & + & 1.02 & 1.65 \\
\hline & & & & soil & BSC & & & + & + & & & & & & & + & $\mathrm{n} / \mathrm{d}$ & $\mathrm{n} / \mathrm{d}$ \\
\hline 2012 & 9.8 & 250 & 3.4 & brine & P-bloom & & & & & & & & & & & & - & - \\
\hline 2013 & 9.8 & 100 & 0.6 & brine & $\mathrm{CB}$ & & & + & & & & & & & & & $\mathrm{n} / \mathrm{d}$ & $\mathrm{n} / \mathrm{d}$ \\
\hline \multirow[t]{3}{*}{2014} & 10.1 & 100 & 0.7 & brine & P-bloom & & & & & & & & & & & & - & - \\
\hline & & & & soil & green BSC & & + & & + & + & + & & & & & & 7.14 & $n / d$ \\
\hline & & & & soil & brown BSC & & & + & + & + & + & & & & & & 0.11 & 0.05 \\
\hline \multirow[t]{3}{*}{2015} & 10.2 & 60 & 0.6 & brine & P-bloom & & & & & & & & & & & & - & - \\
\hline & & & & brine & $\mathrm{CC}$ & & + & & + & & & & + & & & & 2.29 & 2.52 \\
\hline & & & & littoral & $\mathrm{CC}$ & & & + & & & & + & & & & & 1.23 & 0.04 \\
\hline \multirow[t]{2}{*}{2016} & 9.9 & 60 & 0.6 & brine & CC, P-bloom & & & & & & & & & & & & - & - \\
\hline & & & & soil & BSC & & & + & + & & & & & & & & 0.07 & 0.01 \\
\hline \multirow[t]{2}{*}{2018} & 10.1 & 13 & $\mathrm{n} / \mathrm{d}$ & brine & ?-bloom & & & & & & & & & & & & $\mathrm{n} / \mathrm{d}$ & $\mathrm{n} / \mathrm{d}$ \\
\hline & & & & brine & Epiphytic CB & + & + & & + & + & & + & & + & & & $\mathrm{n} / \mathrm{d}$ & $\mathrm{n} / \mathrm{d}$ \\
\hline \multirow[t]{2}{*}{2019} & $\mathrm{n} / \mathrm{d}$ & 14 & $\mathrm{n} / \mathrm{d}$ & brine & CB-bloom & & & & + & + & & + & & + & + & & $\mathrm{n} / \mathrm{d}$ & $\mathrm{n} / \mathrm{d}$ \\
\hline & & & & brine & Epiphytic CB & + & + & & + & + & + & + & + & & & & $\mathrm{n} / \mathrm{d}$ & $\mathrm{n} / \mathrm{d}$ \\
\hline
\end{tabular}

Cyanobacteria: Np - both Nostoc cf. paludosum and N. cf. punctiforme, Nh - Nodularia harveyana, G - Geitlerinema sp., N Nodosilinea sp., H - Halomicronema cf. excentricum, P - Phormidium cf. etoshii, S - Spirulina spp., Ct - Chroococcus turgidus, Cc - cf. Cyanobacterium cedrorum, Mw - Merismopedia warmingiana, E - Euhalothece sp.; NF: ARR - acetylene reduction rates; values in italics mean that ARR is given in $n m o l \mathrm{C}_{2} \mathrm{H}_{4} / \mathrm{g} \cdot \mathrm{h} ; n / d$ no data.

Since heterocystous cyanobacteria are more efficient diazotrophs than other groups of cyanobacteria, this survival strategy may contribute to the supply of bound nitrogen to soda lake ecosystems during both wet and dry periods.

\section{Conclusions}

Thus, the ecosystem of soda lake Tanatar VI includes water body, its littoral area and surrounding soils. Tanatar VI represents a highly dynamic ecosystem with long-standing fluctuations of salinity, which cause succession of phototrophic communities that was not observed in the other studied soda lakes of this region (Namsaraev et al., 2018; Samylina et al., 2019).

\section{Acknowledgements}

This work was supported by the Russian Foundation for Basic Research (grant 19-04-00377) and Ministry of Science and Higher Education of the Russian Federation. The authors are grateful to D.Yu. Sorokin (INMI RAS) for the organization of fieldworks and valuable discussions.

\section{References}

Namsaraev Z., Samylina O., Sukhacheva M. et al. 2018. Effect of salinity on diazotrophic activity and microbial composition of phototrophic communities from Bitter-1 soda lake (Kulunda Steppe, Russia). Extremophiles 22: 651-663. DOI: $10.1007 /$ s00792-018-1026-7

Samylina O.S., Namsaraev Z.B., Grouzdev D.S. et al. 2019. The patterns of nitrogen fixation in haloalkaliphilic phototrophic communities of Kulunda Steppe soda lakes (Altai, Russia). FEMS Microbiology Ecology 95. DOI: 10.1093/ femsec/fiz174

Samylina O.S., Sapozhnikov F.V., Gainanova O.Yu. et al. 2014. Algo-bacterial communities of the Kulunda Steppe (Altai Region, Russia) soda lakes. Microbiology (Mikrobiologiya) 83: 849-860. DOI: 10.1134/S0026261714060162 